\title{
The Effect of Register Instruction on EFL Learners' Writing Performance
}

\author{
Mohammad Yousefi Osguee ${ }^{1}$, Nader Assadi Aidinlou ${ }^{1} \&$ Masoud Zoghi \\ ${ }^{1}$ Department of English Language Teaching, Ahar Branch, Islamic Azad University, Ahar, Iran \\ Correspondence: Mohammad Yousefi Osguee, Islamic Azad University, Ahar, Iran. E-mail: \\ Yoosefimohammad@yahoo.com
}

Received: September 26, 2016 Accepted: October 18, 2016 Online Published: January 12, 2017

doi:10.5539/ijel.v7n1p153 URL: http://dx.doi.org/10.5539/ijel.v7n1p153

\begin{abstract}
The purpose of the present study was twofold. First, it examined the effect of a register-based approach to writing instruction based on the insights gained from Systemic Functional Linguistics (SFL). Second, it attempted to examine the perceptions of the participants toward the register-based approach to writing. To this end, 100 intermediate and advanced students were selected and assigned to two experimental groups (advanced and intermediate ones) and two control groups. Prior to any instruction, the participants of all groups were assigned a writing task as a pre-test. The experimental groups were treated with SFL-oriented register knowledge for 20 sessions while control groups were exposed to the traditional method of teaching writing. Following the treatment, a post test was administered to the groups. The results revealed that the participants in the experimental groups surpassed their counterparts in the control groups. The results of qualitative analysis also disclosed that learners held positive attitudes towards this approach as it heightened their interest in writing.
\end{abstract}

Keywords: register, systemic functional linguistics, writing

\section{Introduction}

An exhaustive review of the literature would reveal the proliferation of research on how to improve the writing skill (Holme, 2004). This increase in research studies indicates that teaching writing is in the forefront of investigations and appropriate methodology to tackle the persistent impediments hindering EFL learners' writing progress is required.

Research findings confirm evidence that prolific studies converge on the beneficial effect of instruction, each tapping into different areas of concern, underscoring various approaches to writing instruction. Most teachers approached writing emphasizing the final product. In this product-focused approach, instruction primarily emphasized sentence structure and grammar and little attention was paid to thinking. Others focused on writing process neglecting the parameters of the context of situation. Such multiplicity of approaches to teaching writing, ranging from product- and process-oriented to genre-based instruction, stems from the consensus among researchers on the writing being the most complex and demanding skill for learners to master (Nunan, 1989; Tribble, 1997; Richards \& Renandya, 2003; Harmer, 2007; Zoghi \& Reshadi, 2014; Salma, 2015), not to mention the difficulties residing in writing in one's own native language (Maftoon, Birjandi, \& Pahlavani, 2014), thus given more prominence as an interesting subject for research.

Among prime reasons lying behind a learner's failure to write well is what was underlined by Harklau (2002), addressing the subordinate place writing has taken up in classroom language learning settings, asserting that its indispensable role in language acquisition has slipped into oblivion. Compounding the problem, according to Ling (2013), is the undue emphasis placed upon accuracy at the expense of overlooking appropriateness. What leads to successful writing, as Hedge (2005) argues, is more than producing clear and accurate sentences since learners must be aided to write and express their ideas in the most appropriate ways. The construction of grammatically accurate sentences per se fails to guarantee successful and effective conveyance of the intended messages. Rather it is the appropriate selection of content, language and levels of formality which serves as a stepping-stone to successful writing (Tuan, 2011), the accomplishment of which calls for a meaning-oriented approach to language which can inform writers' socially and culturally-appropriate choices of language.

In a similar vein, touching a chord with many educators in the field of writing pedagogy are the notions put 
forward by Hallidaian Systemic Functional Linguistics (SFL). Functional linguists attempted to revive grammar by taking a functional approach which deems language as a meaning-making resource, a social phenomenon which is the realization of the social processes enacted in the society (Halliday, 1985). The prime purpose of SFL is to shed light on how language choices are fashioned by particular features of the context (Fang \& Schleppegrell, 2008).

Within the Halliday's systemic functional grammar, the concept of Context of situation, is defined as "the immediate environment in which a text is actually functioning". What gives weight to the context of situation lies in the fact that the meaning residing in an utterance cannot be assembled from the combination of the constituents of that utterance; rather, it is elicited in regard to the situational context in which it occurs (Eggins, 2004). Context of situation embraces the concept of register which was defined by Halliday (Halliday \& Hassan, 1985, p. 89) as "variation according to use", configured by 3 basic components of field, tenor and mode. The field of situation represents the processes (what is happening in a text), the participants (who or what is involved), and the circumstances relating to the time, manner, cause, place and so on (Coffin, 2010).

Putting SFL under the spotlight, Chiang (2013) confirmed the applicability of SFL framework to various educational contexts and its adaptability to learners ranging from elementary to adult learners. More importantly, Chiang's exploration into SFL theory brought into light the successful infusion of it into writing classrooms. Research carried out at the university of Massachusetts by ACCELA (Access to Critical Content and English Language Acquisition) Alliance focused on the use of SFL "both as an analytic and a teaching tool to identify the rhetorical and linguistic patterns prominent in the genres found in K-12 instructional contexts" (Accurso \& Gebhard, in press; Gebhard, Chen, Graham, \& Gunawan, 2013; Gebhard, Chen, Britton, \& Graham, 2014; Gebhard \& Shin, 2011; Ramirez, 2014; Schulze, 2009, 2011; Schulze \& Ramirez, 2007; Shin, Gebhard, \& Seger, 2010; Willett \& Correa, 2014, cited in Schulze, 2015). According to Schulze (2015), ACCELA researchers also investigated the employment of SFL-based pedagogy with the aim of enabling English language learners to engage in different academic literacy practices.

Moreover, the effectiveness of using SFL to improve report writing in primary grades (Brisk \& Zisselberger, 2010) and academic writing (Drysdale \& O'Connor, 2011) added to a growing body of research on the infusion of SFL into educational practices. The results of both studies pointed towards the efficacy of SFL-based pedagogy in facilitating meta-linguistic awareness which led to "an increased control of organization, audience awareness and textual cohesion." (Schulze, 2015, p. 112)

The difficulties posed by writing in an EFL context include interlingual transfer (Gomma, 2010), learners' poor linguistic awareness along with incompetent knowledge of English cohesion rules (Dastjerdi \& Samian, 2011), insufficient knowledge of collocational patterns (Araghi, Yousefi, \& Salehpour, 2014), deficient micro and macro skills (Birjandi, Alavi, \& Salmani Nodushan, 2004), inability to use writing strategies (Beare, 2000), inadequate vocabulary knowledge (Robab'ah, 2003), lack of writing self-efficacy (Bandura, 1994), lack of exposure to language (Adas \& Bakir, 2013), paucity of reading (Al-Mansour \& Al-Shorman, 2014), lack of grammatical knowledge (Huy, 2015), and overemphasis on accuracy at the sentence level rather than discoursal level (Kubota, 1998).

As far as challenges to EFL writing are concerned, Iranian EFL context is by no means an exception, in light of the fact that both the syllabus and textbooks heavily place the emphasis on grammar, vocabulary and reading which prevail over listening, speaking and writing assigned a subservient role. In an analysis of Iranian ELT textbooks, Azizifar, Koosha, \& Lotfi (2010) reported that the materials are solely confined to mechanical drills which stifle learners' motivation to develop communicative skills. What is more, instruction even in language institutes is seemingly oblivious to the prominence of writing, given the fact that classroom time is dominated by listening, speaking and reading with a scant regard for writing which is usually cast aside cursorily as a homework assignment.

Not surprisingly, the writing ability of Iranian EFL learners irrefutably stagnates in view of the fact that it does not receive the due attention it merits. Hence, failure to make headway with writing, which lags far behind other skills, in view of the negligence on the part of both teachers and learners as well as textbook developers has prompted researchers and educationalists in the field to explore every avenue to alleviate the problems Iranian EFL learners have with writing.

Drawing upon the notions put forward by Hallidaian SFL, Assadi (2011) demonstrated the helpfulness of using a discourse-based framework for the teaching of writing on the basis of SFL which tangibly proved beneficial to Iranian students majoring in TEFL. In a similar line, Mosayebnezhad \& Assadi Aidinlou (2015) aimed at improving Iranian EFL high school students through systemic genre instruction rooted in Hallidaian SFL, 
backing up the helpfulness of infusing SFL into Iranian educational practices, corroborating the findings of previous research (Zhang, 2008) in terms of the effectiveness of the overt teaching of formal background knowledge and genre.

However, to the best of the present authors' knowledge, despite the abundance of research centering around the concept of genre, as yet, no study has been devoted to explore the possibilities of improving Iranian EFL learners' writing performance by tapping into SFL and taking a register-based approach to teaching writing. Hence, taking into consideration the point illustrated by Mosayebnazhad \& Assadi (2015) regarding such problems as goal-setting and the organization of written materials posed to Iranian EFL learners, compounded with the problem of socio-cultural factors, we come to the inescapable conclusion that the remedy to the problem is deploying a process which takes students beyond the sentence level engaging them in text manipulation at discourse level. We assume that in an SFL-based process in which the more attuned the learners become to language meta-functions upon reflection, the more proper linguistic choices they come up with, which are sensitive to the context they are apt to interact in. Such methodology would call for raising students' awareness of what is happening, who is involved and how the flow of information is actually presented thereby, attaching prominence to the components of register; namely, field, tenor and mode.

Thus, the current study was an attempt to find out whether drawing upon register theory rooted in Hallidaian SFL can bring about beneficial changes in Iranian EFL intermediate and advanced learners' writing performance or not. Two levels were chosen to make inter-level analysis possible, and in order to get feedback from the students for further improvements a questionnaire was designed.

To this end, the following research questions were formulated:

RQ\#1: Does SFL-oriented register-based approach to teaching writing improve intermediate EFL learners' writing performance?

RQ\#2: Does SFL-oriented register-based approach to teaching writing improve advanced EFL learners' writing performance?

RQ\#3: What are the attitudes of the participants, who received SFL-oriented register-based approach, toward this instruction?

In order to explore the above-mentioned questions the following null hypotheses were formulated:

H0\#1: SFL-oriented register-based approach to teaching writing doesn't improve intermediate EFL learners' writing performance.

H0\#2: SFL-oriented register-based approach to teaching writing doesn't improve advanced EFL learners' writing performance.

H0\#3: Students don't have a positive attitude toward this approach.

\section{Method}

\subsection{Participants}

The participants in this study included 100 male and female advanced/intermediate English students aged between 24 and 35. The participants were selected out of 150 students by employing a PBT TOEFL test to guarantee their initial homogeneity. Once chosen for the study, the participants randomly fell into four groups representing experimental groups and control groups respectively, each including 25 participants.

\subsection{Design}

The present study drew on an experimental pre-test post-test design with two control groups and was intended to estimate the effect of the independent variable, i.e., register-based approach to teaching writing, and proficiency level on the dependent variable of the research which was writing performance.

\subsection{Instruments}

Different instruments were used in this study, including a proficiency test, a pre-test, sample essays, a post-test and a questionnaire.

The first instrument was a PBT TOEFL test selected from Longman Preparation Tests for TOEFL. It was initially utilized to ensure the homogeneity of the participants for the study. The test included 4 sections of the PBT TOEFL test: Listening (50 items), Structure (15 multiple-choice and 25 error-recognition items), Reading (50 items), with the maximum possible score of 140, with each correct answer given 1, and each incorrect answer receiving 0 . 
The participants in both experimental and control groups, preceding the instruction, were assigned a writing test. The specified genre of this writing test which was employed as the pre-test of the study was exposition. All participants were required to write an essay on globalization within 30 minutes. The topic was opted for on the basis of its prevalence in TOEFL tests and students' familiarity with it.

Twenty sample essays were selected from Barron's TOEFL essays (2009), which contains model essays to assist students to write better, to be collaboratively scrutinized during the 20 instructional sessions, with one sample essay to be analytically perused each and every session.

Subsequent to the twenty-session treatment based on an appropriate lesson plan, the participants in both experimental and control groups were assigned another writing test similar to the one employed as the pre-test. The topic of the post-test writing was global warming. The scores of both pre- and post-test, which were out of 30, were given using checklists designed based on the scoring checklists of ETS for the TOEFL iBT writing.

In an attempt to identify the attitude of the participants in both intermediate and advanced experimental groups towards the register-based writing instruction, a questionnaire was employed at the end of the experiment. The questionnaire was framed in a simple coherent style, avoiding any ambiguities, composed of multiple-choice and short answer questions. It had 10 items aiming at eliciting students' retrospection on the writing process and their feedback on the new method.

\subsection{General Procedures}

The whole procedure commenced with engaging students in purposeful reading of the sample essays for the purpose of linguistic analysis of the texts. The participants' analytical attempts were scaffolded by the instructor, which placed in his hand the opportunity to detect potential challenges posed to his students and pinpoint areas which required further elaboration or explicit instruction.

The analysis was initially built around the element of "field", through the examination of processes, participants and circumstances. This involved the identification of, firstly, the central process underlying the text; that is, figuring out the main theme which the text unfolded to depict; secondly, who is involved in the process and their roles, and finally circumstances and whether they informed the how, when and where of the process. Through such analysis of the field, not only did the instructor enlarge his students' understanding of what the language was actually used to talk about, but also maximized the opportunities for them to broaden their current lexicon regarding the field through total immersion, and meticulous analysis of the language utilized to portray the field.

Subsequently, the participants were engaged in the analysis of "tenor", which revolved around the examination of how the text reflected the relationships between participants, their social status, distance, power relations and levels of formality or informality, digging into aspects of mood, modality and appraisal. The analysis of tenor aimed at raising students' awareness of how interpersonal relationships are shaped through particular language choices by the participants involved in the communication. To conclude, through the analysis of the mode, what the instructor mainly made transparent to his students was the textual conveyance of the text, elaborating on aspects of theme, rheme, repetition and conjunction. In short, students in the experimental group were directly exposed to the concepts of experiential, interpersonal, and textual meaning as the treatment.

On the other hand, for the control group, the regular product-oriented approach was utilized which focused on sample writing analysis, writing task, and error correction. The students in the control group were first given a sample essay on the topic taken from the ETS Guide. The teacher helped the students to analyze the sample focusing on grammatical structures, and related vocabulary, and then they were asked to write their own writing on the topic. The following session students' writings were corrected, and they were asked to pay attention to their mistakes in order not to repeat them.

Finally, after twenty sessions, a writing post-test was assigned to both groups. In order to minimize scorer unreliability, both the writing pre-tests and post-tests were scored by two different scorers, and the reliability was estimated through Pearson Correlation.

\section{Results}

The data obtained from the PBT TOEFL test, used to test the homogeneity of participants in both groups, were analyzed using the statistical package for social sciences version 16 (SPSS, 16). As it is shown in Table 1 and 3 , the mean score of both advanced and intermediate students' in experimental groups on the PBT TOEFL test are almost similar to the mean score of advanced and intermediate students in control groups. To ensure that the difference was statistically significant or not, an independent samples t-test was conducted, the results of which revealed that there was not a significant difference between the advanced students' performance on the PBT TOEFL test $(p=.77>.05)$. 
Table 1. Descriptive statistics for the results of PBT TOEFL test for advanced students

\begin{tabular}{llllll}
\hline & groups of students & $\mathrm{N}$ & Mean & Std. Deviation & Std. Error Mean \\
\hline advanced students' scores & Experimental & 25 & 111.88 & 4.978 & .996 \\
& Control & 25 & 111.68 & 5.080 & 1.016 \\
\hline
\end{tabular}

Table 2. Descriptive statistics for the results of the independent samples test

\begin{tabular}{|c|c|c|c|c|c|c|c|c|c|c|}
\hline & & \multicolumn{2}{|c|}{$\begin{array}{l}\text { Levene's Test for } \\
\text { Equality of Variances }\end{array}$} & \multicolumn{7}{|c|}{ T-test for Equality of Means } \\
\hline & & \multirow[t]{2}{*}{$\mathrm{F}$} & \multirow[t]{2}{*}{ Sig. } & \multirow[t]{2}{*}{$\mathrm{T}$} & \multirow[t]{2}{*}{$\mathrm{df}$} & \multirow[t]{2}{*}{$\begin{array}{l}\text { Sig. } \\
\text { (2-tailed) }\end{array}$} & \multirow[t]{2}{*}{$\begin{array}{l}\text { Mean } \\
\text { Difference }\end{array}$} & \multirow[t]{2}{*}{$\begin{array}{l}\text { Std. Error } \\
\text { Difference }\end{array}$} & \multicolumn{2}{|c|}{$\begin{array}{l}95 \% \text { Confidence } \\
\text { Interval of the } \\
\text { Difference }\end{array}$} \\
\hline & & & & & & & & & Lower & Upper \\
\hline \multirow[t]{2}{*}{$\begin{array}{l}\text { Advanced } \\
\text { students' scores }\end{array}$} & $\begin{array}{l}\text { Equal variances } \\
\text { assumed }\end{array}$ & .080 & .778 & .141 & 48 & .889 & .200 & 1.422 & -2.660 & 3.060 \\
\hline & $\begin{array}{l}\text { Equal variances not } \\
\text { assumed }\end{array}$ & & & .141 & 47.980 & .889 & .200 & 1.422 & -2.660 & 3.060 \\
\hline
\end{tabular}

Similarly, to guarantee the homogeneity of the intermediate students in both experimental and control groups another independent samples t-test was conducted which, as shown in Table 4, indicated that the difference between the intermediate experimental and control groups' performance on PBT TOEFL test was not statistically significant $(p=.93>.05)$.

Table 3. Descriptive statistics for the results of the PBT TOEFL test for intermediate students

\begin{tabular}{llllll}
\hline & groups of students & $\mathrm{N}$ & Mean & Std. Deviation & Std. Error Mean \\
\hline \multirow{2}{*}{ Intermediate students' scores } & Experimental & 25 & 85.08 & 7.963 & 1.593 \\
\cline { 2 - 6 } & Control & 25 & 82.72 & 8.101 & 1.620 \\
\hline
\end{tabular}

Table 4. Descriptive statistics for the results of the independent samples test

\begin{tabular}{|c|c|c|c|c|c|c|c|c|c|c|}
\hline & & \multicolumn{2}{|c|}{$\begin{array}{l}\text { Levene's Test for } \\
\text { Equality of Variances }\end{array}$} & \multicolumn{7}{|c|}{ T-test for Equality of Means } \\
\hline & & \multirow[t]{2}{*}{$\mathrm{F}$} & \multirow[t]{2}{*}{ Sig. } & \multirow[t]{2}{*}{$\mathrm{T}$} & \multirow[t]{2}{*}{$\mathrm{df}$} & \multirow[t]{2}{*}{$\begin{array}{l}\text { Sig. } \\
\text { (2-tailed) }\end{array}$} & \multirow[t]{2}{*}{$\begin{array}{l}\text { Mean } \\
\text { Difference }\end{array}$} & \multirow[t]{2}{*}{$\begin{array}{l}\text { Std. Error } \\
\text { Difference }\end{array}$} & \multicolumn{2}{|c|}{$\begin{array}{l}95 \% \text { Confidence } \\
\text { Interval of the } \\
\text { Difference }\end{array}$} \\
\hline & & & & & & & & & Lower & Upper \\
\hline \multirow[t]{2}{*}{$\begin{array}{l}\text { Intermediate } \\
\text { students' scores }\end{array}$} & $\begin{array}{l}\text { Equal variances } \\
\text { assumed }\end{array}$ & .008 & .930 & 1.039 & 48 & .304 & 2.360 & 2.272 & -2.208 & 6.928 \\
\hline & $\begin{array}{l}\text { Equal variances } \\
\text { not assumed }\end{array}$ & & & 1.039 & 47.986 & .304 & 2.360 & 2.272 & -2.208 & 6.928 \\
\hline
\end{tabular}

In order to compare the performance of advanced students in experimental and control groups on the writing pre-tests, another independent samples t-test was conducted, the results of which, as shown in Table 5 and 6 , are indicative of no significant difference between them $(p=.765>.05)$.

Table 5. Descriptive group statistics for the results of writing pre-test for advanced students

\begin{tabular}{llllll}
\hline & groups of students & $\mathrm{N}$ & Mean & Std. Deviation & Std. Error Mean \\
\hline \multirow{2}{*}{$\begin{array}{l}\text { advanced students' pre-test } \\
\text { scores }\end{array}$} & Experimental & 25 & 20.5200 & 1.68622 & .33724 \\
\cline { 2 - 6 } & Control & 25 & 19.2000 & 1.84842 & .36968 \\
\hline
\end{tabular}


Table 6. Descriptive group statistics for the results of independent samples t-test

\begin{tabular}{|c|c|c|c|c|c|c|c|c|c|c|}
\hline & & \multicolumn{2}{|c|}{$\begin{array}{l}\text { Levene's Test for } \\
\text { Equality of Variances }\end{array}$} & \multicolumn{7}{|c|}{ T-test for Equality of Means } \\
\hline & & \multirow[t]{2}{*}{$\mathrm{F}$} & \multirow[t]{2}{*}{ Sig. } & \multirow[t]{2}{*}{$\mathrm{T}$} & \multirow[t]{2}{*}{ df } & \multirow[t]{2}{*}{$\begin{array}{l}\text { Sig. } \\
\text { (2-tailed) }\end{array}$} & \multirow[t]{2}{*}{$\begin{array}{l}\text { Mean } \\
\text { Difference }\end{array}$} & \multirow[t]{2}{*}{$\begin{array}{l}\text { Std. Error } \\
\text { Difference }\end{array}$} & \multicolumn{2}{|c|}{$\begin{array}{l}95 \% \text { Confidence Interva } \\
\text { of the Difference }\end{array}$} \\
\hline & & & & & & & & & Lower & Upper \\
\hline $\begin{array}{l}\text { Advanced } \\
\text { students' }\end{array}$ & $\begin{array}{l}\text { Equal variances } \\
\text { assumed }\end{array}$ & .091 & .765 & 2.638 & 48 & .011 & 1.32000 & .50040 & .31388 & 2.32612 \\
\hline $\begin{array}{l}\text { pre-test } \\
\text { scores }\end{array}$ & $\begin{array}{l}\text { Equal variances } \\
\text { not assumed }\end{array}$ & & & 2.638 & 47.601 & .011 & 1.32000 & .50040 & .31366 & 2.32634 \\
\hline
\end{tabular}

Likewise, the same procedure was undertaken to compare the performance of the intermediate students in experimental and control groups on the writing pre-test. The results, as apparent from Table 7 and 8 , indicate no statistically significant difference between the performance of intermediate experimental and control groups on the writing pre-test.

Table 7. Descriptive group statistics for the results of writing pre-test for intermediate students

\begin{tabular}{llllll}
\hline & groups of students & $\mathrm{N}$ & Mean & Std. Deviation & Std. Error Mean \\
\hline intermediate students' & intermediate experimental & 25 & 17.1200 & 1.56312 & .31262 \\
pre-test scores & intermediate control & 25 & 16.8800 & 1.61555 & .32311 \\
\hline
\end{tabular}

Table 8. Descriptive group statistics for the results of independent samples t-test

\begin{tabular}{|c|c|c|c|c|c|c|c|c|c|c|}
\hline & & \multicolumn{2}{|c|}{$\begin{array}{l}\text { Levene's Test for } \\
\text { Equality of Variances }\end{array}$} & \multicolumn{7}{|c|}{ T-test for Equality of Means } \\
\hline & & \multirow[t]{2}{*}{$\mathrm{F}$} & \multirow[t]{2}{*}{ Sig. } & \multirow[t]{2}{*}{$\mathrm{T}$} & \multirow[t]{2}{*}{$\mathrm{df}$} & \multirow[t]{2}{*}{$\begin{array}{l}\text { Sig. } \\
\text { (2-tailed) }\end{array}$} & \multirow[t]{2}{*}{$\begin{array}{l}\text { Mean } \\
\text { Difference }\end{array}$} & \multirow[t]{2}{*}{$\begin{array}{l}\text { Std. Error } \\
\text { Difference }\end{array}$} & \multicolumn{2}{|c|}{$\begin{array}{l}95 \% \text { Confidence Interval } \\
\text { of the Difference }\end{array}$} \\
\hline & & & & & & & & & Lower & Upper \\
\hline \multirow{2}{*}{$\begin{array}{l}\text { Intermediate } \\
\text { students' pre-test } \\
\text { scores }\end{array}$} & $\begin{array}{l}\text { Equal variances } \\
\text { assumed }\end{array}$ & .034 & .854 & .534 & 48 & .596 & .24000 & .44959 & -.66397 & 1.14397 \\
\hline & $\begin{array}{l}\text { Equal variances } \\
\text { not assumed }\end{array}$ & & & .534 & 47.948 & .596 & .24000 & .44959 & -.66399 & 1.14399 \\
\hline
\end{tabular}

To compare the means of both groups' writing post-tests and to test whether their difference was statistically significant due to register-based instruction, independent samples t-tests were conducted both for the results of advanced and intermediate students' writing post-test, comparing their performance between experimental and control groups. Table 9 shows that the mean score of participants in advanced experimental group $(M=26.88)$ is higher than that of control group ( $M=20.20)$. The difference is indicated to be statistically significant as shown in Table 10. $(p=.005<.05)$

Table 9. Descriptive group statistics for the results of writing post-test for advanced students

\begin{tabular}{llllll}
\hline & groups of students & $\mathrm{N}$ & Mean & Std. Deviation & Std. Error Mean \\
\hline advanced students' & experimental & 25 & 26.8800 & 1.09240 & .21848 \\
post-test scores & Control & 25 & 20.2000 & 1.91485 & .38297 \\
\hline
\end{tabular}


Table 10. Descriptive group statistics for the results of the independent samples t-test

\begin{tabular}{|c|c|c|c|c|c|c|c|c|c|c|}
\hline & & \multicolumn{2}{|c|}{$\begin{array}{l}\text { Levene's Test for } \\
\text { Equality of Variances }\end{array}$} & \multicolumn{7}{|c|}{ T-test for Equality of Means } \\
\hline & & \multirow[t]{2}{*}{$\mathrm{F}$} & \multirow[t]{2}{*}{ Sig. } & \multirow[t]{2}{*}{$\mathrm{T}$} & \multirow[t]{2}{*}{$\mathrm{df}$} & \multirow[t]{2}{*}{$\begin{array}{l}\text { Sig. } \\
\text { (2-tailed) }\end{array}$} & \multirow[t]{2}{*}{$\begin{array}{l}\text { Mean } \\
\text { Difference }\end{array}$} & \multirow[t]{2}{*}{$\begin{array}{l}\text { Std. Error } \\
\text { Difference }\end{array}$} & \multicolumn{2}{|c|}{$\begin{array}{l}95 \% \text { Confidence Interva } \\
\text { of the Difference }\end{array}$} \\
\hline & & & & & & & & & Lower & Upper \\
\hline \multirow[t]{2}{*}{$\begin{array}{l}\text { Advanced } \\
\text { students' scores }\end{array}$} & $\begin{array}{l}\text { Equal variances } \\
\text { assumed }\end{array}$ & 8.693 & .005 & 15.151 & 48 & .000 & 6.68000 & .44091 & 5.79349 & 7.56651 \\
\hline & $\begin{array}{l}\text { Equal variances } \\
\text { not assumed }\end{array}$ & & & 15.151 & 38.126 & .000 & 6.68000 & .44091 & 5.78752 & 7.57248 \\
\hline
\end{tabular}

The same procedure was carried out for the intermediate students' performance on the writing post-test. As indicated by the mean scores of writing post-test for both experimental and control groups in Table 11, intermediate students in the experimental group $(\mathrm{M}=23.00)$ outperform their counterparts in the control group $(\mathrm{M}=17.80)$. The results of Table 12 revealed that the difference was statically significant $(p=.017<.05)$.

Table 11. Descriptive group statistics for the results of writing post-test for intermediate students

\begin{tabular}{llllll}
\hline & groups of students & $\mathrm{N}$ & Mean & Std. Deviation & Std. Error Mean \\
\hline intermediate students' & experimental & 25 & 23.0000 & 1.82574 & .36515 \\
post-test scores & Control & 25 & 17.8000 & 1.08012 & .21602 \\
\hline
\end{tabular}

Table 12. Descriptive group statistics for the results of independent samples t-test

\begin{tabular}{|c|c|c|c|c|c|c|c|c|c|c|}
\hline & & \multicolumn{2}{|c|}{$\begin{array}{l}\text { Levene's Test for } \\
\text { Equality of Variances }\end{array}$} & \multicolumn{7}{|c|}{ T-test for Equality of Means } \\
\hline & & \multirow[t]{2}{*}{$\mathrm{F}$} & \multirow[t]{2}{*}{ Sig. } & \multirow[t]{2}{*}{$\mathrm{T}$} & \multirow[t]{2}{*}{ df } & \multirow[t]{2}{*}{$\begin{array}{l}\text { Sig. } \\
\text { (2-tailed) }\end{array}$} & \multirow[t]{2}{*}{$\begin{array}{l}\text { Mean } \\
\text { Difference }\end{array}$} & \multirow[t]{2}{*}{$\begin{array}{l}\text { Std. Error } \\
\text { Difference }\end{array}$} & \multicolumn{2}{|c|}{$\begin{array}{l}95 \% \text { Confidence } \\
\text { Interval of the } \\
\text { Difference }\end{array}$} \\
\hline & & & & & & & & & Lower & Upper \\
\hline \multirow[t]{2}{*}{$\begin{array}{l}\text { Intermediate } \\
\text { students' scores }\end{array}$} & $\begin{array}{l}\text { Equal variances } \\
\text { assumed }\end{array}$ & 6.120 & .017 & 12.257 & 48 & .000 & 5.20000 & .42426 & 4.34696 & 6.05304 \\
\hline & $\begin{array}{l}\text { Equal variances } \\
\text { not assumed }\end{array}$ & & & 12.257 & 38.967 & .000 & 5.20000 & .42426 & 4.34182 & 6.05818 \\
\hline
\end{tabular}

Furthermore, the analysis of students' attitudes revealed that $92 \%$ of advanced students and $88 \%$ of intermediate ones believed that their writing had improved significantly and they held a positive view towards this approach.

\section{Discussion}

Considering the results, we could come up with the answers to our research questions, which were about the effect of the register-based approach on the writing performance of the students, and we were able to reject all null hypotheses. This approach exerted a positive influence on improving students' writing skill in both intermediate and advanced levels. One of the primary goals of this study was to examine the applicability of the SFL framework to teaching writing in Iranian context. In spite of the fact that SFL has much to offer in EFL education, more research needs to be done in order to conclude that a pedagogy based on it would prosper in Iranian settings. The results of this research are congruent with the findings of similar previous studies (Brisk \& Zisselberger, 2010; Chiang, 2013; Drysdale \& O'Connor, 2011; Mosayebnazhad \& Assadi Aidinlou, 2015) about the effect of SFL on teaching writing. Familiarity with the context of situation can act as a kind of proper scaffolding for the students, and it helps them throughout the writing process. They come to an understanding that meaning is derived and expressed in relation to the situational context.

Based on the findings of this study as well as other related research (Gibbons, 2009; Schulze, 2009), it can be postulated that Iranian intermediate and advanced students can benefit in writing provided that they are given formal teaching on register; that is, the field, tenor, and mode of the discourse. Familiarizing students with these concepts assists them to build up a text in relation to the context of situation which concentrates on the 
mentioned proponents of a communicative event. Accordingly, the first priority in instruction is to illustrate the features of register, which is feasible and meaningful approach to improve learners' writing proficiency by improving the appropriateness of their writing. The participants in this study maintained a positive view to this approach, and were fond of it.

Considering what has been said, it can be concluded that an SFL orientation to writing can aid students in analyzing the language both globally and locally. Globally, they are empowered to ponder over the schematic structure of the text, and locally they are enabled to evaluate logical and semantic relationships at the sentence level. This framework takes students beyond the local level, and introduces a broader perspective by familiarizing students with the components of register. They come to an understanding that the meaning of an utterance does not exist in the ideas of the words comprising it but it is derived from the situational context. This novelty in Iranian EFL context, where local aspects prevail in teaching writing, can pave the way for having better performance on the part of the students, and educators can reap its benefits.

\section{References}

Adas, D., \& Bakir, A. (2013). Writing difficulties and new solutions: Blended learning as an approach to improve writing abilities. International Journal of Humanities and Social Science, 3(9), 254-266.

Ahmadi, D., Maftoon, P., \& Gholami Mehradad, A. (2012). Investigating the effects of two types of feedback on EFL students' writing. Procedia Social and Behavioral Sciences, 46, 2590-2595. https://doi.org/10.1016/j.sbspro.2012.05.529

Alavi, S. M., \& Ashari Tabar, N. (2012). The effect of task type and pre-task planning condition on the accuracy of intermediate EFL learners' writing performance. The Journal of Applied Linguistics, 5(1), 36-60.

Al-Mansour, N. S., \& Al-Shorman, R. A. (2014). The effect of an extensive reading program on the writing performance of Saudi EFL university students. International Journal of Linguistics, 6(2), 258-275. https://doi.org/10.5296/ijl.v6i2.5551

Assadi Aidinlou, N. (2011). A discourse-based teaching of writing for Iranian EFL students: A systemic perspective. Journal of English Language Teaching and Learning, 8, 53-70.

Azizifar, A., Koosha, M., \& Lotfi, A. R. (2010). An Analytical Evaluation of Iranian High School ELT Textbooks from 1970 to the Present. Procedia Social and Behavioral Sciences. http://dx.doi.org/10.1016/j.sbspro.2010.07.010.

Bandura, A. (1994). Self-Efficacy. In V. S. Ramachaudran (Ed.), Encyclopedia of human behavior (pp. 71-81). New York: Academic Press.

Beare, S. (2000). Differences in content generating and planning processes of adult L1 and L2 proficient writers. Unpublished $\mathrm{PhD}$ dissertation, University of Ottawa.

Brisk, M., \& Zisselsberger, M. (2010). We've let them in on a secret: Using SFL theory to improve the teaching of writing to bilingual learners. In T. Lucas (Ed.), Preparing all teachers to teach English language learners (pp. 111-126). Mahwah, NJ: Erlbaum/Taylor \& Francis.

Celce-Murcia, M., \& Olshtain, E. (2000). Discourse and context in language teaching: A guide for language teachers. Cambridge: Cambridge University Press.

Coffin, C. (2010). Language support in EAL contexts. Why systemic functional linguistics? (Special Issue of NALDIC Quarterly). NALDIC. Reading, UK.

Dastjerdi, H., \& Samian, H. S. (2011). Quality of Iranian EFL learners' Argumentative Essays: Cohesive Devices in Focus. Mediterranean Journal of Social Sciences, 2(2), 65-76.

Derewianka, B., \& Jones, P. (2010). Policy, practice and research. From traditional grammar to functional grammar: bridging the divide. (Special Issue of NALDIC Quarterly). NALDIC. Reading, UK.

Eggins, S. (2004). An introduction to systemic functional linguistics. London, England: Pinter.

Fang, Z., \& Schleppegrell, M. J. (2008). Reading in secondary content areas: A language-based pedagogy. Ann Arbor, MI: The University of Michigan Press.

Folkeryd, J. W. (2006). Writing with an Attitude. Appraisal and student texts in the school subject of Swedish. Acta Universitatis Upsaliensis. Studia Linguistica Upsaliensia 5. Uppsala.

Gebhard, M., \& Martin, J. (2010). Grammar and literacy learning. In D. Fisher \& D. Lapp (Eds.), Handbook of Research on Teaching the English Language Arts (3rd ed., pp. 297-304). Mahwah, NJ: Erlbaum/Taylor \& 
Francis.

Gebhard, M., Chen, I. A., Graham, H., \& Gunawan, W. (2013). Teaching to mean, writing to mean: SFL, L2 literacy, and teacher education. Journal of Second Language Writing, 22, 107-124. https://doi.org/10.1016/j.jslw.2013.03.005

Gebhard, M., Willett, J., Jimenez, J., \& Piedra, A. (2010). Systemic functional linguistics, teachers' professional development, and ELLs' academic literacy practices. In T. Lucas (Ed.), Teacher Preparation for Linguistically Diverse Classrooms: A resource for teacher educators (pp. 91-110). Mahwah, NJ: Erlbaum/Taylor \& Francis.

Gibbons, P. (2009). English learners, academic literacy and thinking: learning in the challenge zone. Portsmouth, NH: Heinemann.

Gomma, L. (2010). Writing trouble spots for ESL students of Arabic: The apple where teachers meet and learn.

Grabe, W., \& Kaplan, R. B. (1996). The theory and practice of writing. Addison Wesley: Longman Limited.

Halliday, M. A. K. (1978) Language as social semiotic: the social interpretation of language and meaning. Baltimore: University Park Press.

Halliday, M. A. K., \& Hasan, A. S. (1985). Language, context, and text: aspects of language in a social-semiotic perspective. Victoria: Deakin University Press.

Halliday, M. A. K., \& Hasan, R. (1989). Language, context and text: aspects of language in a social-semiotic perspective. Hong Kong: Oxford University Press.

Halliday, M. A. K., \& Matthiessen, C. M. I. M. (2004). An introduction to functional grammar. London: Arnold.

Harklau, L. (2002). The role of writing in classroom second language acquisition. Journal of Second Language Writing, 11, 329-350. https://doi.org/10.1016/S1060-3743(02)00091-7

Harmer, J. (2007). The practice of English language teaching. Harlow: Pearson Education Limited.

Hedge, T. (2005). Writing (p. 104). Oxford: Oxford University Press.

Holme, R. (2004). Literacy: An Introduction. Edinburgh: Edinburgh University Press.

Huy, N. T. (2015). Problems affecting learning writing skill of grade 11 at Thong Linh high school. Asian Journal of Educational Research, 3(2), 53-69.

Kubota, R. (1998). An investigation of L1-L2 transfer in writing among Japanese university students: Implications for contrastive rhetoric. Journal of Second Language Writing, 7(1), 69-100. https://doi.org/10.1016/S1060-3743(98)90006-6

Ling, Z. (2013). Register theory in functional linguistics and its implication in language teaching. International conference on educational research and sports education, pp. 164-168.

Maftoon, P., Birjandi, P., \& Pahlavani, P. (2014). Mapping (CAAM) on the improvement of writing achievement of Iranian learners of English. Theory and Practice in Language Studies, 4(5), 982-988. https://doi.org/10.4304/tpls.4.5.982-988

Martin, J. R. (2009). Genre and language learning: A social semiotic perspective. Linguistics and Education, 20, 10-21. https://doi.org/10.1016/j.linged.2009.01.003

Mosayebnazhad, F., \& Assadi Aidinlou, N. (2015). The effect of the systemic genre instruction on the writing performance of Iranian EFL high school students. MAGNT Research Report, 3(1), 377-388.

Naderi Kalali, N., \& Pishkar, K. (2015). Genre analysis and writing skill: Improving Iranian learners writing performance through the tenets of genre analysis. Advances in Language and Literacy studies, 6(6), 119-130.

Nunan, D. (1989). Designing tasks for the communicative classroom. Cambridge: Cambridge University Press.

Pakbaz, R., \& Rezai, M. J. (2015). The effect of task repetition and consciousness-raising on Iranian L2 learners' writing performance. International Journal of Language and Applied Linguistics, 1(2), 49-57.

Rabiee, M. (2008). Two collaborative feedback models in EFL writing instruction: Do they make a difference? The Journal of Applied linguistics, 1(3), 134-163.

Richards, J. C., \& Renandya, W. A. (2003). Methodology in language teaching: An anthology of current practice (3rd ed.). Cambridge: Cambridge University Press. 
Robab'ah, G. (2003). Communication Problems facing Arab learners of English: A personal perspective. TEFL Web Journal, 2(1), 15-30.

Safari, I., \& Mokhtari, S. A. (2016). The effect of genre-based oral academic lectures on writing achievement among Iranian male and female TOEFL learners. Global Journal of Interdisciplinary Social Sciences, 5(2), $34-42$.

Salma, U. (2015). Problems and Practical Needs of Writing Skill in EFL Context: An Analysis of Iranian Students of Aligarh Muslim University. Journal of Humanities and Social Science, 20(11), 74-76.

Schulze, J. (2009) Testing, testing: the ideational meta-function in high stakes testing materials Colombian Applied Linguistics Journal, 11, 80-92.

Schulze, J. (2011). Writing to persuade: A systemic functional view. GIST Educational Research and Teaching Journal, 5, 127-157.

Schulze, J. (2015). Academic language, English language learners, and systemic functional linguistics: Connecting theory and practice in teacher education. The CATESOL Journal, 27(1), 109-130.

Seifoori, Z., Zeraatpishe, M., \& Ahangari, S. (2012). The impact of task-supported interactive feedback on the accuracy, fluency, and organization of Iranian EFL learners' writing. Journal of Applied Linguistics, 5(1), 239-270.

Tribble, C. (1997). Writing. Oxford: Oxford University Press.

Tuan, L. T. (2011). Teaching writing through genre-based approach. Theory and Practice in Language studies, 1(11), 1471-1478. https://doi.org/10.4304/tpls.1.11.1471-1478

Williams, G. (2005). Grammatics in schools. In J. Webster, C. Matthiessen, \& R. Hasan (Eds.), Continuing Discourse on Language, 1, 281-310. London: Equinox.

Zare-ee, A. (2009). The effects of teaching genre moves on EFL learners' performance in letter writing. Pazhuhesh-e Zabanha-ye Khareji, 49, 43-64.

Zhang, X. (2008). The effects of formal schema on reading comprehension-An experiment with Chinese EFL readers. Computational Linguistics and Chinese language Processing, 13(2), 197-214.

Zoghi, M., \& Reshad, E. (2014). A study of lexical ties used in medical science articles written by Iranian and English authors. International Journal of English Language Education, 2(1).

\section{Copyrights}

Copyright for this article is retained by the author(s), with first publication rights granted to the journal.

This is an open-access article distributed under the terms and conditions of the Creative Commons Attribution license (http://creativecommons.org/licenses/by/4.0/). 